\title{
IMPLEMENTASI PEMBELAJARAN PKN BERBASIS INKLUSI DI HOMESCHOOLING
}

\author{
Ahmad Nasir Ari Bowo \\ Pendidikan Pancasila dan Kewarganegaraan Universitas Cokroaminoto Yogyakarta \\ Jl. Perintis Kemerdekaan, Gambiran, Umbulharjo, Kota Yogyakarta 55161 \\ Email: ahmadnasir@ucy.ac.id
}

\begin{abstract}
ABSTRAK
Penelitian ini bertujuan untuk mendeskripsikan implementasi pembelajaran PKn berbasis inklusi di homeschooling kota Yogyakarta. Metode penelitian ini menggunakan pendekatan kualitatif. Hasil penelitian menunjukkan bahwa di homeschooling Anak Pelangi Yogyakarta, dalam merencanakan dan mengembangkan pembelajaran inklusi sesuai dengan karakteristik siswa. Di awal masuk atau pendaftaran, calon siswa terlebih dahulu melakukan test fingerprint dan psikotest. Hal tersebut dimaksudkan untuk mendapatkan kesimpulan tentang bakat, minat, dan potensi anak, sehingga memudahkan pihak guru dalam mengembangkan potensi anak sesuai dengan kebutuhannya. Bidang akademik dan psikologi akan memberikan hasil test kepada guru yang digunakan sebagai rekomendasi dan referensi untuk penanganan serta metode mengajar yang tepat bagi siswa, dengan demikian guru dapat mengembangkan kurikulum sesuai dengan karakteristik siswa.

Adapun Pelaksanaan pembelajaran di Homeschooling lebih singkat dibanding sekolah formal pada umumnya. Dengan jumlah tatap muka dan durasi lebih singkat, maka guru dapat menyampaikan materi-materi sesuai kemampuan masing-masing siswa. Dapat diketahui bahwa, penerapan pembelajaran PPKn Inklusi Homeschooling Yogyakarta antara lain: (a) ketika test masuk calon siswa baru, mereka melakukan test fingerprint, dan psikotest, (b) hasil test fingerprint dan psikotest digunakan untuk mengetahui karakteristik, potensi, latar belakang, dari siswa, (c) guru menerapkan kurikulum KTSP yang dikembangkan sesuai dengan keadaan siswa.
\end{abstract}

Kata Kunci: Pembelajaran, PKn, Berbasis Inklusi, Homeschooling

ABSTRACT
This study aims to describe the implementation of inclusive civics learning in homeschooling in Yogyakarta. This research method uses a qualitative approach. The results showed that in the homeschooling of Anak Pelangi Yogyakarta, in planning and developing inclusive learning in accordance with student characteristics. At the beginning of entry or registration, prospective students first do a fingerprint and psychological test. It is intended to get conclusions about the talents, interests, and potential of children, making it easier for teachers to develop children's potential according to their needs. Academic and psychological fields will provide test results to teachers that are used as recommendations and references for handling and teaching methods that are appropriate for students, so teachers can develop curricula in accordance with student characteristics.

The implementation of learning in Homeschooling is shorter than formal schools in general. With the number of face-to-face and shorter duration, the teacher can deliver materials according to the abilities of each student. It can be seen that, the application of PPKn Yogyakarta Homeschooling Inclusion learning includes: (a) when the test enters prospective new students, they conduct a fingerprint test, and a psychological test, $(b)$ the results of the fingerprint test and a psychological test are used to determine the characteristics, potential, background, of students, (c) the teacher applies an SBC curriculum that is developed according to the student's circumstances.

Keywords: Learning, Civics, Inclusion Based, Homeschooling 


\section{PENDAHULUAN}

Pendidikan adalah suatu proses dalam rangka mempengaruhi siswa agar dapat menyesuaikan diri sebaik mungkin terhadap lingkungannya sehingga akan menimbulkan perubahan dalam dirinya yang memungkinkannya untuk berfungsi secara kuat dalam kehidupan masyarakat (Hamalik, 2003: 79). Usia anak-anak dan remaja adalah usia yang produktif dalam mengenyam dunia pendidikan untuk mendapatkan ilmu pengetahuan. Tidak heran, dunia pendidikan telah membuat sistem pendidikan yang sudah tertata dan terkonsep. Mulai jenjang Play Group/KB, TK, Sekolah dasar, sekolah menengah, sampai Perguruan Tinggi. Selain itu, model-model pendidikan pun juga bervariasi. Misalnya saja Boarding Schools, Program khusus, Homeschooling, Sekolah Terpadu, dan lain sebagainya, yang kesemuanya itu untuk mewujudkan tujuan pendidikan yang diharapkan. Namun, tak lepas dari itu, masih banyak juga usia anak atau remaja di Indonesia yang belum begitu menyadari tentang arti pentingnya pendidikan atau ilmu pengetahuan. Malas-malas'san, bosan, takut, tidak nyaman dalam proses pembelajaran teryata masih menjadi teman yang selalu setia menemani mereka di saat proses pembelajaran disekolah. Sehingga apabila hal tersebut terus terjadi pada diri siswa, maka akan berdampak pada kurang berhasilnya tujuan pembelajaran yang diharapkan.

Berikut ini beberapa contoh kurang berhasilnya guru dalam penerapan pembelajaran antara lain hasil penelitian Mulyani (2014: 51) menyatakan bahwa model pembelajaran yang dilakukan di SMKN I Depok masih cenderung menggunakan metode ceramah dan masih cenderung ke arah kognitif. Selain itu Simbolon (2014: 226) mengungkapkan Guru-guru SMA Negeri Medan umumnya masih menggunakan pembelajaran konvensional dalam pembelajaran, yaitu pembelajaran yang masih berpusat pada guru (teacher centered approach). Dengan menggunakan pembelajaran konvensional tersebut, siswa kurang terpacu menyalurkan kreativitasnya dalam berpikir dan belajar, karena semua materi pelajaran sudah dipersiapkan oleh guru. Hasil penelitian lain tentang perencanaan pembelajaran oleh guru di SMP Negeri 23 Padang dalam setting Inklusi menyimpulkan bahwa perencanaan pembelajaran oleh guru bidang studi Biologi di SMP N 23 Padang belum dapat terlaksana dengan baik. Hal ini terbukti dengan tidak adanya perencanaan pembelajaran yang dibuat oleh guru bidang studi Biologi dalam menghadapi anak berkebutuhan khusus dengan gangguan pendengaran yang ada di kelasnya. Dalam perencanaan pembelajarannya disamaratakan saja antara peserta didik yang berkebutuhan khusus dengan peserta didik yang normal. Sehingga menyebabkan anak berkebutuhan khusus kurang mampu dalam mengikuti pembelajaran Biologi dengan baik. Anak berkebutuhan khusus menjadi kurang tertarik dengan pembelajaran yang diterapkan, tidak konsentrasi dalam 
menerima pembelajaran yang diberikan (Praptiningrum; 2013: 303). Rendahnya tingkat kesadaran dalam proses pembelajaran oleh peserta didik banyak dipengaruhi beberapa faktor. Salah satunya adalah faktor tutor atau guru dalam menyampaikan pembelajaran serta pendekatannya kepada peserta didik. Idealnya, seorang guru haruslah mampu mempengaruhi peserta didiknya untuk menerima rangsangan melalui pembelajaran yang diberikan dengan menerapkan Joyful learning.

Terkait hal itu, permasalahan tersebut juga berlaku di pendidikan model Homeschooling di Yogyakarta. Hasil pengamatan peneliti, dapat diketahui bahwa masih ada peserta didik yang malas-malasan, kurang aktif, berkeliaran, bahkan ada yang sering keluar masuk kelas di saat proses pembelajaran. Selain itu hasil wawancara dan sharing peneliti dengan beberapa guru homeschooling di Yogyakarta, memperlihatkan bahwa masih ada beberapa peserta didik yang sulit di atur, tidak mau memperhatikan di saat proses pembelajaran, dan ada juga yang sulit menerima materi karena keterbatasan. Apabila permasalahan tersebut terus menerus terjadi, akan berakibat bahwa peserta didik belum mampu memahami materi dengan baik, sehingga tujuan pembelajaran tidak akan tercapai. Solusi dalam mengatasi permasalahan tersebut, salah satunya adalah menerapkan Joyful learning oleh guru. Selain guru menerapkan berbagai strategi pembelajaran yang di buat oleh ahli di bidangnya, Guru juga harus mampu mengembangkan atau mengkolaburasikan berbagai model pembelajaran tersebut, sehingga lebih bisa men-joyful learning-kan, tentu di saat proses pembelajaran berlangsung. Sehingga, tujuan pembelajaran di harapkan bisa tercapai.

Selain itu, cara penyampaian guru di saat proses pembelajaran juga perlu di perhatikan. Idealnya seorang guru tidak harus membentak atau menghukum peserta didik dengan berbagai cara yang menakutkan atau memberatkan. Apabila hal tersebut terjadi, maka akan berdampak pada hal yang tidak baik bagi peserta didik itu sendiri. Misalnya, ketakutan, depresi dan hal-hal negatif lainnya. Seorang guru haruslah dapat menerapkan pembelajaran inklusif baik dari cara penyampaian di saat proses pembelajaran, atau dalam memperlakukan peserta didik di dalam pembelajaran. Penelitian ini akan memfokuskan tentang implementasi pembelajaran PPKn berbasis inklusi. Adapun fokus penelitian ini dilaksanakan di homeschooling Anak Pelangi kota Yogyakarta jenjang SMP kelas VIII. Meskipun peneliti mengimplementasikan penelitian ini melalui pembelajaran PPKn tetapi hal tersebut bisa diterapkan di berbagai mata pelajaran dan jenjang pendidikan sekalipun. Keberhasilan dalam implementasi model ini akan dibuktikan pada pemahaman konsep dan prestasi akademik. Lebih lanjut akan di uraian dalam tujuan penelitian. Adapun tujuan penelitian ini adalah (1) mendeskripsikan menemukan model implementasi pembelajaran PPKn berbasis inklusi yang di laksanakan oleh guru Homeschooling. 
PPKn mempunyai peran penting dalam membentuk karakter kepribadian bangsa. Dewasa ini banyak berbagai permasalahan bangsa, salah satunya adalah degradasi moral pada generasi muda. Maka dari itu PPKn sangat berperan penting dalam mengatasi permasalahan tersebut. Berdasarkan Undang-undang Nomor 20 Tahun 2003 tentang Sistem Pendidikan Nasional pasal 37 ayat 1-2 disebutkan bahwa PPKn merupakan mata pelajaran wajib pada pendidikan dasar, menengah, maupun tinggi. PPKn dimaksudkan agar bangsa Indonesia memiliki kesadaran sebagai warga Negara. Sumarsono dkk. (2005:4), menyatakan tujuan utama PPKn adalah untuk menumbuhkan wawasan dan kesadaran berwarganegara, sikap serta perilaku yang cinta tanah air dan bersendikan kebudayaan bangsa, wawasan nusantara, serta ketahanan nasional dalam diri para mahasiswa calon sarjana/ilmuwan warga negara Negara Kesatuan Republik Indonesia yang sedang mengkaji dan akan menguasai iptek dan seni.

Pendidikan Kewarganegaraan yang berhasil akan terwujud sikap, perilaku yang baik dan bertanggung jawab, sehingga bangsa Indonesia khusunya pelajar mempunyai kesadaran hukum yang tinggi. Keberhasilan pembelajaran PPKn sangat dipengaruhi dalam proses pembelajaran. maka dari itu penggunaan model dan strategi pembelajaran sangatlah penting untuk mewujudkan tujuan pembelajaran. Pembelajaran inklusi (Inclusive education) merupakan ideologi, system dan atau strategi dalam penyelenggaraan pendidikan, dimana anak-anak berkebutuhan khusus memperoleh layanan pendidikan dalam lingkungan belajar yang sama bersama anak-anak lainnya secara bermutu dan sesuai kebutuhannya (Supena: 2009: 4). Selanjutnya Manisah dkk. (2006:01) mengungkapkan bahwa the hallmark of inclusive education is the teachers' willingness to accept students with special needs. Their attitudes and knowledge about inclusive education are important as these are indicators of such willingness Pembelajaran inklusi dianggap merupakan strategi yang efektif untuk menuntaskan wajib belajar 9 tahun, bagi anakanak berkebutuhan khusus.

Hal ini dimungkinkan karena anak dapat memperoleh pendidikan pada sekolah manapun yang terdekat dengan rumah tinggalnya. Di sisi lain, model ini juga dianggap lebih efisien karena tidak perlu mendirikan sekolah khusus untuk mereka. Pembelajaran inklusif juga lebih memungkinkan siswa berkebutuhan khusus melakukan pembelajaran emosi dan sosial secara lebih wajar. Di sisi lain, model ini juga mendorong siswa lain untuk belajar menghargai dan menerima anak-anak berkebutuhan khusus (Smith, dalam Supena; 2009: 4). Sisi positif dari pendidikan inklusi telah banyak diketahui dan diakui oleh banyak pihak, tetapi wujud konkrit dari pelaksanaan pendidikan inklusi tampaknya belum begitu jelas khususnya bagi para pelaksana pendidikan di tingkat sekolah. Dewasa ini, semua sekolah di tuntut untuk bisa menerapkan pembelajaran inklusi. Akan tetapi belum semua sekolah paham akan penerapan 
pembelajaran inklusi tersebut. Pembelajaran inklusi pada dasarnya tidak hanya terfokus pada anak berkebutuhan khusus. Namun, juga semua peserta didik karena setiap peserta didik mempunyai kenikan masing-masing.

\section{METODE PENELITIAN}

Penelitian ini merupakan penelitian kualitatif. Tempat penelitian ini adalah di Homeschooling Anak Pelangi Kota Yogyakarta yang beralamat di Jalan Taman Siswa Nomor 160 D.I. Yogyakarta. Subjek dalam penelitian ini adalah guru PPKn dan siswa kelas VIII A dan B SMP Homeschooling Anak Pelangi Yogyakarta. Teknik pengumpulan data yang digunakan dalam penelitian ini adalah dengan teknik observasi, wawancara, dan dokumentasi. Menurut Sukmadinata (2009: 220) "Observasi atau pengamatan merupakan suatu teknik cara mengumpulkan data dengan jalan menadakan pengamatan terhadap kegiatan yang sedang berlangsung". Melalui observasi peneliti dapat mengetahui kegiatan siswa dalam mempersiapkan, memperhatikan, menanggapi, penjelasan dari guru selama proses pembelajaran. dalam penelitian ini metode observasi digunakan untuk mengamati siswa dalam proses pembelajaran berlangsung. Selanjutnya, menurut Nawawi dan Martini (1992: 98) wawancara merupakan alat yang digunakan dalam komunikasi yang berbentuk sejumlah pertanyaan lisan yang diajukan oleh pengumpul data sebagai pencari informan yang di jawab lesan pula oleh responden. Wawancara yang di gunakan dalam penelitian ini adalah wawancara bebas. Metode wawancara digunakan untuk memperkuat dan memperjelas data yang diperoleh melalui metode observasi, yaitu data mengenai pemahaman konsep dan prestasi akademik siswa kelas VIII Homeschooling Anak Pelangi Kota Yogyakarta.

Menurut pendapat Moleong (1991:175-178) dalam penelitian ini pengujian keabsahan data penulisan dilakukan dengan cara perpanjangan pengamatan dan triangulasi. Perpanjangan keikutsertaan peneliti akan memungkinkan peningkatan derajat kepercayaan data yang dikumpulkan. Selain itu keikutsertaan juga dimaksudkan untuk membangun kepercayaan para subjek terhadap peneliti dan juga kepercayaan peneliti sendiri. Menurut Patton (1987:329) sebagaimana dikutip Moleong (1991:178) triangulasi dilakukan dengan cara memanfaatkan metode, ini berarti peneliti mengadakan pengecekan derajat kepercayaan penemuan hasil penelitian beberapa teknik pengumpulan data dan pengecekan derajat kepercayaan beberapa sumber data dengan metode yang sama. Penelitian ini menggunakan observasi dan wawancara untuk sumber data yang sama secara serempak.

Ada beberapa teknik yang dapat digunakan untuk mengetahui validitas data (kestabilan data). Penelitian ini menggunakan dua macam triangulasi, yang pertama triangulasi sumber data 
yang berupa informasi dari guru dan siswa tentang tindakan yang diterapkan. Kedua triagulasi teknik atau metode pengumpulan dari hasil observasi dan wawancara. Analisis data dalam penelitian ini menggunakan teknik analisis data model alir. Adapun langkah-langkah teknik analisis data menurut Miles dan Huberman (1992: 15-19) adalah sebagai berikut:

1. Pengumpulan data, yaitu mengumpulkan data di lokasi penelitian dengan melakukan observasi, wawancara, dan dokumentasi dengan menentukan strategi pengumpulan data yang dipandang tepat dan untuk menentukan fokus serta pendalaman data pada proses pengumpulan data berikutnya.

2. Reduksi data, yaitu sebagai proses pemilihan, pemfokusan, pengabstrakan, transformasi data kasar yang ada di lapangan langsung, dan diteruskan pada waktu pengumpulan data, dengan demikian reduksi data dimulai sejak peneliti mulai memfokuskan wilayah penelitian.

3. Penyajian data, yaitu rakitan organisasi informasi yang memungkinkan adanya penarikan kesimpulan saat penelitian dilakukan. Dalam penyajian data diperoleh berbagai jenis metrik gambar, jaringan kerja, keterkaitan kegiatan atau tabel.

4. Penarikan kesimpulan, yaitu dalam pengumpulan data, peneliti harus mengerti dan tanggap terhadap sesuatu yang diteliti langsung di lapangan dengan menyusun pola-pola pengarahan dan sebab-akibat.

\section{HASIL DAN PEMBAHASAN}

Kurikulum Pendidikan informal/nonformal di Indonesia sampai sekarang ini masih di arahkan menggunakan kurikulum tingkat satuan pendidikan (KTSP) tahun 2006. Wawancara dengan koordinator bidang akademik pada tanggal 14 September 2016, dapat diketahui bahwa "kurikulum yang di gunakan di Homeschooling masih menggunakan kurikulum KTSP". Penerapan kurikulum yang digunakan pada kelas VIII berpedoman pada kurikulum KTSP. Namun, guru dapat mengembangkan kurikulum tersebut sesuai dengan karakteristik masingmasing siswa. Berpedoman pada Garnida (2015: 122-127) hal-hal yang perlu dilakukan dalam pembelajaran inklusif antara lain:

a. Merencanakan kegiatan pembelajaran, antara lain: menetapkan tujuan, merencanakan pengelolaan kelas, merencanakan pengorganisasian bahan, merencanakan pengelolaan kegiatan pembelajaran, merencanakan penggunaan sumber belajar, dan merencanakan penilaian.

b. Melaksanakan kegiatan pembelajaran, antara lain: 1) berkomunikasi dengan siswa, b) mengimplementasikan metode, sumber belajar, dan bahan pelatihan yang sesuai dengan tujuan pembelajaran, 3) mendorong siswa untuk terlibat secara aktif, 4) mendemonstrasikan 
penguasaan materi dan relevansinya dalam kehidupan, 5) mengelola waktu, ruang, bahan, dan perlengkapan pengajaran, 6) mengelola pembelajaran kelompok yang kooperatif, 7) melakukan evaluasi. Selanjutnya hubungan antar pribadi dapat di wujudkan dalam bentuk : 1) bersikap terbuka, toleran, dan simpati terhadap siswa, 2) menampilkan kegairahan dan kesungguhan dan 3) mengelola interaksi antar pribadi.

Di Homeschooling Anak Pelangi Yogyakarta, dalam merencanakan dan mengembangkan pembelajaran inklusi yang sesuai dengan karakteristik siswa, maka di awal masuk atau pendaftaran, calon siswa terlebih dahulu melakukan test fingerprint dan psikotest. Hal tersebut dimaksudkan untuk mendapatkan kesimpulan tentang bakat, minat, dan potensi anak. Wawancara dengan divisi kurikulum mengungkapkan bahwa "untuk mengetahui karakteristik, bakat, dan potensi siswa, maka terlebih dulu, kami melakukan tes fingerprint dan psikotest, hal tersebut di maksudkan untuk memudahkan pihak guru dalam mengembangkan potensi anak sesuai dengan kebutuhannya." Selain itu divisi akademik juga menambahkan bahwa, "test finger print dan psikotest dapat memudahkan kami dalam hal pengembangan kurikulum yang di lakukan oleh guru, dan mengetahui bakat, karakteristik dan potensi siswa". "pelaksanaan test ini pihak Homeschooling bekerjasama dengan lembaga lain, namun dalam operasionalnya dilapangan, tetap kami yang melakukan".

Bidang akademik dan psikologi akan memberikan hasil test kepada guru yang digunakan sebagai rekomendasi dan referensi untuk penanganan serta metode mengajar yang tepat bagi siswa, dengan demikian guru dapat mengembangkan kurikulum sesuai dengan karakteristik siswa. Adapun Pelaksanaan pembelajaran di Homeschooling lebih singkat dibanding sekolah formal pada umumnya. Dengan jumlah tatap muka dan durasi lebih singkat, maka guru dapat menyampaikan materi-materi sesuai kemampuan masing-masing siswa. Adapun contoh rencana pelaksanaan pembelajaran pada kelas VIII pada mata pelajaran PKn sebagaimana di paparkan dalam uraian berikut ini.

\section{RENCANA PELAKSANAAN PEMBELAJARAN \\ (RPP)}

\section{Identitas Sekolah}

$\begin{array}{ll}\text { Mata Pelajaran } & \text { : PKn } \\ \text { Pokok Bahasan } & \text { : Pancasila Sebagai Dasar Negara } \\ \text { Tingkatan / Setara Kelas } & \text { : VIII (Delapan) } \\ \text { Semester } & : 1 \text { (Satu) } \\ \text { Alokasi Waktu } & : 60 \text { menit (1 x Pertemuan) }\end{array}$

\section{A. Standar Kompetensi}

1. Menampilkan perilaku yang sesuai dengan nilai-nilai Pancasila 


\section{B. Kompetensi Dasar}

1.1 Menjelaskan Pancasila sebagai dasar negara dan ideologi negara

\section{Indikator pencapaian kompetensi}

1. Siswa mampu menjelaskan pengertian dasar negara

2. Siswa mampu menjelaskan Pancasila sebagai dasar negara

3. Siswa mampu menjelaskan pengertian ideologi negara

4. Siswa mampu menerapkan nilai-nilai Pancasila dalam kehidupan sehari-hari

Nilai Budaya dan Karakter Bangsa : Religius, jujur, toleransi, disiplin, kerja keras, mandiri, demokratis, rasa ingin tahu, semangat kebangsaan, cinta tanah air, menghargai prestasi, bersahabat, cinta damai, gemar membaca, peduli lingkungan, peduli sosial, tanggung jawab, mandiri.

Kewirausahaan/Ekonomi Kreatif: 1) Percaya diri (keteguhan hati, optimis), 2) Berorientasi pada tugas (bermotivasi, tekun, tabah, bertejat, enerjik), 3) Pengambil resiko (suka tantangan, mampu memimpin), 4) Orientasi ke masa depan (punya perspektif untuk masa depan).

\section{Tujuan Pembelajaran}

Setelah selesai proses pembelajaran, siswa diharapkan dapat :

1. Menjelaskan pengertian dasar negara

2. Menjelaskan Pancasila sebagai dasar Negara

3. Menjelaskan Pancasila sebagai Ideologi negara

4. Menerapkan nilai-nilai Pancasila sebagai dasar negara

\section{E. Materi Pembelajaran}

1. Pengertian dasar negara

2. Pengertian Pancasila sebagai dasar negara

3. Pengertian Pancasila sebagai Ideologi Negara

4. Nilai-nilai Pancasila dalam kehidupan sehari-hari

\section{F. Metode Pembelajaran}

Ceramah dan Diskusi bervariasi

\section{G. Kegiatan Pembelajaran}

Langkah-langkah kegiatan pembelajaran :

Pertemuan pertama

\begin{tabular}{|l|l|l|c|}
\hline No & \multicolumn{1}{|c|}{ Kegiatan Guru } & Kegiatan Peserta Didik & Alokasi Waktu \\
\hline 1. & $\begin{array}{l}\text { Pendahuluan } \\
\text { a. Kegiatan awal: salam, berdoa, } \\
\text { menanyakan keadaan peserta } \\
\text { didik. }\end{array}$ & $\begin{array}{l}\text { a. Menjawab salam, berdoa, } \\
\text { dan menjawab pertanyaan } \\
\text { guru. }\end{array}$ & 5, \\
$\begin{array}{l}\text { b. Apersepsi: Merivew materi } \\
\text { sebelumnya } \\
\text { c. Motivasi peserta didik }\end{array}$ & $\begin{array}{l}\text { bendengarkan penjelasan } \\
\text { guru }\end{array}$ & \\
\hline $\begin{array}{l}\text { Kegiatan Inti } \\
\text { a. Eksplorasi }\end{array}$ & a. Mendengarkan penjelasan & 45, \\
\hline
\end{tabular}




\begin{tabular}{|c|c|c|c|}
\hline & $\begin{array}{l}\text { Dalam kegiatan eksplorasi: } \\
\text { guru menyampaikan } \\
\text { kompetensi yang ingin di } \\
\text { capai, guru menjelaskan norma } \\
\text { b. Elaborasi } \\
\text { Dalam kegiatan elaburasi: guru } \\
\text { menyuruh siswa untuk } \\
\text { berdiskusi kelompok tentang } \\
\text { norma, tanya jawab, dan } \\
\text { latihan didik } \\
\text { c. Konfirmasi } \\
\text { Dalam kegiatan konfirmasi : } \\
\text { guru dan peserta di } \\
\text { menjelaskan materi yang di } \\
\text { diskusikan. }\end{array}$ & $\begin{array}{l}\text { b. Berdiskusi kelompok } \\
\text { tentang norma tanya jawab, } \\
\text { dan latihan. } \\
\\
\text { c. Peserta didik menjelaskan } \\
\text { materi yang di diskusikan } \\
\text { sebelumnya }\end{array}$ & \\
\hline 3. & $\begin{array}{l}\text { Penutup } \\
\text { Guru melakukan evaluasi dan tanya } \\
\text { jawab kepada peserta didik terkait } \\
\text { materi yang di pelajari, guru dan } \\
\text { peserta didik bersama-sama } \\
\text { menyimpulkan materi, berdoa dan } \\
\text { salam penutup. }\end{array}$ & $\begin{array}{l}\text { Mendengarkan penjelasan guru, } \\
\text { bersama-sama menyimpulkan } \\
\text { materi yang dipelajari, berdoa, } \\
\text { dan salam penutup }\end{array}$ & $10^{\prime}$ \\
\hline
\end{tabular}

H. Alat/Media Pembelajaran

Kertas portofolio, Laptop, alat tulis.

\section{Sumber Belajar}

1. Buku PKn Kelas VII Penerbit Erlangga

2. Buku PKn Kelas VII Penerbit Yudistira

3. Internet

4. Surat kabar dan atau majalah

\section{J. Penilaian}

1. Penilaian Koqnitif

2. Penilaian Afektif

3. Penilaian Psikomotorik

Yogyakarta, September 2015

Mengetahui,

Guru Mata Pelajaran

$\underline{\text { Ahmad Nasir, S.Pd }}$ 
Dapat diketahui bahwa, penerapan pembelajaran PPKn Inklusi Homeschooling Yogyakarta antara lain:

a. Ketika test masuk calon siswa baru, mereka melakukan test fingerprint, dan psikotest.

b. Hasil test fingerprint dan psikotest digunakan untuk mengetahui karakteristik, potensi, latar belakang, dari siswa

c. Guru menerapkan kurikulum KTSP yang dikembangkan sesuai dengan keadaan siswa.

\section{SIMPULAN}

Bertitik tolak dari penelitian ini, maka dapat di ambil beberapa simpulan sebagai berikut di Homeschooling Anak Pelangi Yogyakarta, dalam merencanakan dan mengembangkan pembelajaran inklusi yang sesuai dengan karakteristik siswa. Di awal masuk atau pendaftaran, calon siswa terlebih dahulu melakukan test fingerprint dan psikotest. Hal tersebut dimaksudkan untuk mendapatkan kesimpulan tentang bakat, minat, dan potensi anak, sehingga memudahkan pihak guru dalam mengembangkan potensi anak sesuai dengan kebutuhannya. Bidang akademik dan psikologi akan memberikan hasil test kepada guru yang digunakan sebagai rekomendasi dan referensi untuk penanganan serta metode mengajar yang tepat bagi siswa, dengan demikian guru dapat mengembangkan kurikulum sesuai dengan karakteristik siswa. Adapun Pelaksanaan pembelajaran di Homeschooling lebih singkat dibanding sekolah formal pada umumnya. Dengan jumlah tatap muka dan durasi lebih singkat, maka guru dapat menyampaikan materi-materi sesuai kemampuan masing-masing siswa. Dapat diketahui bahwa, penerapan pembelajaran PPKn Inklusi Homeschooling Yogyakarta antara lain: (a) ketika test masuk calon siswa baru, mereka melakukan test fingerprint, dan psikotest, (b) hasil test fingerprint dan psikotest digunakan untuk mengetahui karakteristik, potensi, latar belakang, dari siswa, (c) guru menerapkan kurikulum KTSP yang dikembangkan sesuai dengan keadaan siswa.

\section{SARAN}

Berdasarkan pengalaman dalam penerapan pembelajaran PKn berbasis inklusi disarankan beberapa hal sebagai berikut:

\section{Terhadap Kepala Sekolah}

a. Kepala sekolah harus menjadi pemimpin perbaikan pembelajaran dengan melibatkan para guru.

b. Kepala sekolah dapat melakukan pemantauan proses pembelajaran di kelas. Hal ini dapat digunakan untuk mengetahui situasi pembelajaran kelas dan masalah-masalah yang muncul 
dari masing-masing kelas dan berusaha mengatasi permasalahan tersebut tentunya bekerjasama dengan para guru.

c. Kepala sekolah hendaknya menerima dan mendengarkan segala masukan dari guru dengan masalah pembelajaran.

2. Terhadap Guru Kelas

a. Kerja kolaboratif dalam penelitian tindakan kelas dapat dipakai menjadi wahana pembelajaran PKn. Melalui kerja kolaboratif guru kelas akan memiliki gambaran pembelajaran PKn yang efektif, karena penelitian tindakan kelas berdasarkan permasalahan yang kongkrit sehingga gurulah yang paling bisa melakukannya.

b. Guru kelas perlu mengadakan pemantauan perilaku siswa selama proses pembelajaran. Hal ini akan membantu guru untuk memahami setiap permasalahan yang muncul dan dapat dipakai dalam upaya peningkatan kemampuan bertanya dan berpendapat siswa.

\section{Terhadap Siswa}

a. Setiap siswa hendaknya dapat menjalin hubungan yang baik dengan guru maupun bekerja sama dengan teman-temannya agar proses pembelajaran terasa nyaman dan menyenangkan.

b. Siswa hendaknya lebih aktif dalan mengikuti pembelajaran PKn.

c. Siswa hendaknya selalu belajar secara rutin dan berkesinambungan walaupun pertemuan selanjutnya tidak ada ujian.

4. Terhadap Peneliti Berikutnya

Penelitian sejenis hendaknya dilakukan tetapi dalam cakupan materi tertentu dan menggunakan strategi pembelajaran tertentu. Oleh karena itu diperlukan sebuah strategi pembelajaran dari guru yang lebih inovatif, sehingga akan mampu memberikan masukan kepada dunia pendidikan Indonesia secara umum.

\section{DAFTAR PUSTAKA}

Bowo, A. N. A. (2015). Pengembangan Pengelolaan Pembelajaran Ekonomi Berbasis Lingkungan dengan Strategi Small Group Discussion di SMA Muhammadiyah 1 Surakarta. Academy of Education Journal, 6(1).

Bowo, A. N. A. (2015). Cerita Cinta Belajar Mengajar. Deepublish.

Bowo, A. N. A. (2014). Small Group Discussion Berbasis Reading Guide untuk Peningkatan Keaktifan dan Hasil Belajar PKn Siswa MTs. Academy of Education Journal, 5(2).

Hamalik, Oemar. 2003. "Pendidikan Guru Berdasarkan Pendekatan Kompetensi”. Jakarta: Bumi Aksara. 
Manisah Mohd, ali., dkk. 2006. "An Empirical Study on Teachers Perceptions Towards Inclusive Education In Malaysia”. International Journal of Special Education Vol. 21 No. 3. Malaysia: Institute Of Education Science.

Miles, Mathew B. dan Michael Huberman. 1992. "Analisis Data Kualitatif (Buku Sumber tentang Metode-Metode Baru)”. Jakarta: UIP.

Mulyani, Endang. 2014. "Pengembangan Model Pembelajaran Berbasis Projek Pendidikan Kewirausahaan untuk Peningkatan Sikap, Minat, Perilaku Wirausaha, dan Prestasi Belajar Siswa SMK". Journal Cakrawala Pendidikan Nomor 1 Februari. Yogyakarta: UNY.

Moleong, Lexy J. 1990. Metodologi Penelitian Kualitatif. Bandung: PT. Remaja Ros-dakarya.

Nuryati, N., \& Bowo, A. N. A. (2015). Pengembangan Model Pembelajaran PPKn Quantum Teaching Berbasis Lingkungan melalui Cooperative Learning di SMA Negeri Kota Yogyakarta. Academy of Education Journal, 6(2).

Praptiningrum. 2013. "perencanaan pembelajaran oleh guru di SMP Negeri 23 Padang dalam Setting Inklusi”. Jurnal Ilmiah Pendidikan Khusus Volume 2 Nomor 3.Padang: UNP.

Sukmadinata, Nana Syaodih. 2009. Metode Penelitian Pendidikan. Bandung: PT Remaja Rosdakarya.Sumarsono dkk. 2005. Pendidikan Kewarganegaraan. Jakarta: Gramedia Pustaka Utama.

Suyanto, Jihad Asep. 2013. Menjadi Guru Profesional (Strategi meningkatkan kualifikasi dan kualitas guru di era global). Jakarta: Esensi.

Undang-Undang Repoblik Indonesia Nomor 20 Tahun 2003 Tentang Sistem Pendidikan Nasional. 